\title{
PREVALENCE AND CLINICAL SIGNS OF POSTPARTUM DYSGALACTIA SYNDROME AT THE FIRST DAY AFTER FARROWING IN FARMED SOWS IN THE REPUBLIC OF MACEDONIA
}

\author{
Branko Angjelovski ${ }^{1}$, Miroslav Radeski ${ }^{1}$, Igor Djadjovski ${ }^{1}$, Dine Mitrov ${ }^{1}$, \\ Jovan Bojkovski ${ }^{3}$, Nikola Adamov ${ }^{2}$, Toni Dovenski ${ }^{2}$ \\ ${ }^{1}$ Veterinary Institute, Faculty of Veterinary Medicine, \\ Ss. Cyril and Methodius University in Skopje, \\ Lazar Pop Trajkov 5-7, 1000 Skopje, Republic of Macedonia \\ ${ }^{2}$ Institute of Reproduction and Biomedicine, Faculty of Veterinary Medicine, \\ Ss. Cyril and Methodius University in Skopje, \\ Lazar Pop Trajkov 5-7, 1000 Skopje, Republic of Macedonia \\ ${ }^{3}$ Faculty of Veterinary Medicine, University of Belgrade, Bulevar Oslobodjenja 18, \\ 11000 Belgrade, Republic of Serbia
}

Received 20 November 2018; Received in revised form 22 January 2019; Accepted 30 January 2019

\begin{abstract}
The objective of the present study was to determine the prevalence of postpartum dysgalactia syndrome (PDS) and associated clinical signs in farmed sows in the Republic of Macedonia (RM) in the first 12-24 h postpartum. A total of 202 sows of different parity and different genetic lines from 5 pig farms in RM were included in the study. The sows and their litters were clinically examined 12-24 hours after farrowing. Postpartum dysgalactia syndrome was detected in $23.3 \%$ of all clinically examined sows, while prevalence between farms ranged from $14.8 \%$ to $38.1 \%$. Altered piglet's behavior was the most frequent clinical pattern observed in $68.1 \%$ of the PDS-affected (PDSA) sows. Regarding the clinical signs in PDSA sows detected among farms, significant differences were observed in the altered piglet's behavior $(\mathrm{p}<0.05)$ and hypogalactia $(p<0.05)$. Endometritis was more often detected in older sows $(90 \%)$ compared to endometritis in younger animals $(44.4 \%)$. In addition, fever was also more frequently diagnosed in higher parity ( $\geq 3$ parity) sows $(55.0 \%)$ in contrast to other PDSA sows $(22.2 \%)$. This study has demonstrated the presence of PDS in farmed sows in RM. High frequency of altered piglet's behavior found in this study could be an useful indicator for early detection of lactation problems in sows. Frequent pathological vaginal discharge in older sows indicates that endometritis plays an important role in the clinical manifestation of PDS. Further investigations should be conducted in order to identify specific risk factors associated with clinical PDS in farmed sows in RM.
\end{abstract}

Key words: postpartum dysgalactia syndrome, prevalence, sow

\section{INTRODUCTION}

Postapartum dysgalactia syndrome (PDS) is a pathological condition in sows characterized by impaired health and reduced colostrum and milk

Corresponding author: Dr. Branko Angjelovski, $\mathrm{PhD}$

E-mail address: brankoa@fvm.ukim.edu.mk

Present address: Veterinary Institute, Faculty of Veterinary Medicine, Ss. Cyril and Methodius University in Skopje, Lazar Pop Trajkov 5-7, 1000 Skopje, Republic of Macedonia

Phone: +38923240752; Fax: +38923114619

Copyright: (C) 2019 Angjelovski B. This is an open-access article published under the terms of the Creative Commons Attribution License which permits unrestricted use, distribution, and reproduction in any medium, provided the original author and source are credited. Competing Interests: The authors have declared that no competing interests exist.

Available Online First: 15 February 2019

Published on: 15 March 2019

https://doi.org/10.2478/macvetrev-2019-0014 production shortly after farrowing $(1,2)$. The previously used terms MMA or mastitis, metritis and agalactia syndrome, nowadays is considered to be a misnomer since metritis is rarely seen (1) and only few sows have true agalactia (3). This syndrome is associated with great economic losses, due to decreased growth rate and increased mortality in preweaning piglets $(1,2,4)$. It poses a serious problem for animal welfare in pig production and it has been reported worldwide $(5,6)$. Many risk factors such as feeding, routine hygiene and disinfection practices, microclimate conditions and general management are strongly related with the occurence of $\operatorname{PDS}(1,3,6)$. Although it is a multifactorial syndrome, coliform 
bacteria - especially Escherichia coli - play a major role in the clinical manifestations of PDS in affected sows $(7,8,9,10,11,12)$. There are many clinical signs associated with PDS such as mastitis, metritis, hypogalactia, fever, anorexia, constipation and depression $(6,11,13,14)$. According to some studies, mastitis is one of the central clinical signs found in PDS sows $(8,15)$. However, recent studies suggest that endometritis in sows should be considered as an important risk factor for PDS development $(16,17)$. The piglet's nursing behavior is also an essential clinical parameter for recognizing lactation insufficiency in PDS-affected sows (14).

The average incidence of PDS at herd level is approximately $13 \%(6,18,19,20)$, while at farm level the incidence was estimated to be within the range from $0.5 \%$ to $60 \%$ (11). Thus, the incidence of PDS in Swedish herds was 5.5\% in small herds and $10.3 \%$ in large herds (21). In another study in Missouri, out of 27,656 farrowings, $13 \%$ of sows were affected by PDS (22). Recently in Denmark, Larsen and Thorup found a prevalence of $32.5 \%$ on the first day postpartum, $31.5 \%$ on the second day, and $10.1 \%$ on the third day post-partum (23). In a study carried out in
110 Belgian pig herds, PDS was reported as a problem in 34\% during the first 3 days after farrowing (6). This wide range in prevalence is most likely due to the large variation of the symptoms and criteria used to define PDS in sows (3).

Data regarding prevalence and type of clinical signs of PDS in farmed sows in the Republic of Macedonia is missing. Therefore, the aim of this study was to determine the prevalence of PDS and the frequency of associated clinical signs in farmed sows at the first day after farrowing.

\section{MATERIAL AND METHODS}

The study was conducted in 5 commercial pig farms with one site production in Macedonia, during the period between July 2014 and August 2016. The selection of the farms was based according to the number of sows kept in the herd (minimum 100 sows), history of postparturient diseases and willingness of the farmers to participate in the survey. Descriptive data regarding breeding herds characteristics, hygiene routines and general management practices are shown in Table 1.

Table 1. Descriptive data of the breeding herds for all farms

\begin{tabular}{|c|c|c|c|c|c|}
\hline Parameter & Farm A & Farm B & Farm C & Farm D & Farm E \\
\hline $\begin{array}{l}\text { Average parity of } \\
\text { sows }\end{array}$ & 3.3 & 4.2 & 3.7 & 3.5 & 5.5 \\
\hline $\begin{array}{l}\text { Age of gilts at first } \\
\text { insemination (days) }\end{array}$ & 240 & 240 & 240 & 240 & 240 \\
\hline $\begin{array}{l}\text { Cleaning of } \\
\text { farrowing pen } \\
\text { (daily) }\end{array}$ & 2 & 2 & 2 & 2 & 3 \\
\hline Floor farrowing pen & $\begin{array}{l}\text { Completed and } \\
\text { slatted }\end{array}$ & Slatted & Slatted & $\begin{array}{l}\text { Completed and } \\
\text { slatted }\end{array}$ & Slatted \\
\hline $\begin{array}{l}\text { Heating in the } \\
\text { farrowing pen }\end{array}$ & $\begin{array}{c}\text { Combined } \\
\text { (heating plate and } \\
\text { lamp) }\end{array}$ & $\begin{array}{c}\text { Combined } \\
\text { (heating plate and } \\
\text { lamp) }\end{array}$ & $\begin{array}{l}\text { Combined } \\
\text { (heating plate } \\
\text { and lamp) }\end{array}$ & $\begin{array}{l}\text { Combined } \\
\text { (heating plate } \\
\text { and lamp) }\end{array}$ & $\begin{array}{l}\text { Combined (heating } \\
\text { plate and lamp) }\end{array}$ \\
\hline Gestation housing & Individual & Individual & Individual & Group & Group \\
\hline $\begin{array}{l}\text { Days in farrowing } \\
\text { pen before } \\
\text { farrowing }\end{array}$ & $>7$ days & $>7$ days & $>7$ days & $>7$ days & $\leq 4$ days \\
\hline
\end{tabular}


In total, 202 sows with available reproductive data of different parity (from 1 to 9) and different genetic lines (Landrace-Yorkshire F1 and Dalland hybrid) were included in the study (Table 2). Sows with unknown reproductive records (parity number and time of farrowing completion) were excluded from the study.

Table 2. Number of sows per farm included in the study

\begin{tabular}{ccc}
\hline Farm & $\begin{array}{c}\text { Herd size } \\
\text { (no. of sows) }\end{array}$ & $\begin{array}{c}\text { No. of clinically } \\
\text { examined sows }\end{array}$ \\
\hline A & 1000 & 42 \\
B & 675 & 46 \\
C & 766 & 27 \\
D & 600 & 48 \\
E & 100 & 39 \\
\hline Total & 3141 & 202 \\
\hline
\end{tabular}

The sows and their litters were clinically examined for the presence of PDS 12-24 hours after farrowing $(8.00 \mathrm{am}$ to $10.00 \mathrm{am})$. The sows were defined as PDS-affected if more than one of the following clinical signs were found: fever in sows, hypogalactia, mastitis, endometritis, anorexia in sow (total feed refusal), depression in sow and altered piglet's behavior. The fever in sows was diagnosed when their rectal temperature was increased $\left(\geq 39.5^{\circ} \mathrm{C}\right)$ within 12 to 24 hours after farrowing. Mastitis was recorded if signs of inflammation of the mammary glands (severe edema, skin congestion, hardening, pain) were found, whereas hypogalactia in sow was determined if milk flow was drastically reduced (few drops of milk) after oxytocin injection and manual stimulation of mammary glands. Additionally, endometritis was diagnosed in sows which displayed copious purulent vaginal discharge. For ascertaining the site of origin of the discharge, a metal speculum of $3 \mathrm{~cm}$ external diameter with a length of $30-40 \mathrm{~cm}$ and a light bulb were used. Depression in sow was present when lethargy and sternal recumbency were observed, while altered behavior in piglets was detected when they showed restlessness, reduced nursing frequency and general activity and/or preference to the warmest area of the farrowing crate.

Statistical analyses were performed using StatSoft, Inc. (2007), STATISTICA (data analysis software system), version 8.0. The statistical units were the individual sow with the litter and the pig farm. The prevalence of PDS was calculated at animal and farm level, while Chi square-test for independence was used to determine the statistical differences in the prevalence of PDS between the pig farms included in the study. Additionally, Chi square-test for independence was performed to show differences in the frequency of the clinical signs observed among pig farms, while Fisher's exact test was calculated to detect statistical differences in the frequency of clinical signs between lower (1 and 2 parity) and higher ( $\geq 3$ parity) parity sows. The results were considered statistically significant at $p<0.05$.

\section{RESULTS}

Postpartum dysgalactia syndrome was detected in $23.3 \%$ of all clinically examined sows included in the study, while the prevalence between farms ranged from $14.8 \%$ to $38.1 \%$. (Table 3). No significant difference in the prevalence of PDS between the farms was observed $(\chi 2(4)=8.89, p>0.05)$. Considering the number of parity, the prevalence in younger sows (parity 1-2) was $13.4 \%$ (27/202), while prevalence of $9.9 \%$ was found in the older sows (parity $\geq 3$ ).

Table 3. Percentage of PDS-affected (PDSA) and PDS-unaffected (PDSU) sows at all farms

\begin{tabular}{ccc}
\hline Farm & PDSA sows \% & PDSU sows \% \\
\hline A & $38.1(16 / 42)$ & $61.9(26 / 42)$ \\
B & $17.4(8 / 46)$ & $82.6(38 / 46)$ \\
C & $14.8(4 / 27)$ & $85.2(23 / 27)$ \\
D & $27.1(13 / 48)$ & $72.9(35 / 48)$ \\
E & $15.4(6 / 39)$ & $84.6(33 / 39)$ \\
\hline Total & $23.3 \%(47 / 202)$ & $76.7 \%(155 / 202)$ \\
\hline
\end{tabular}

Altered piglet's behavior was the most frequent clinical criterion observed in $68.1 \%(32 / 47)$ of PDSA sows, whereas anorexia was least detected, in 34\% (16/47) of PDSA sows. The frequency of the clinical signs found in PDSA sows is presented in Table 4.

Regarding the frequency of the clinical signs observed in PDSA sows among farms, statistical differences were found in the altered piglet's behavior $\left(\chi^{2}(4)=12.19, \mathrm{p}<0.05\right)$ and hypogalactia $\left(\chi^{2}(4)=9.62,(p<0.05)\right.$. Altered piglet's behavior was found more frequently in PDSA sows from farm A $[75 \%(12 / 16)]$, farm B [100\% (8/8)] and farm C $[100 \%(4 / 4)]$. Hypogalactia was dominant sign in PDSA sows at farm D $(92.3 \%(12 / 13)]$, farm C $[75 \%(3 / 4)]$ and farm A $[62.5 \%(10 / 16)]$. The number of PDSA sows which have exhibited different clinical signs at farm level is presented in Table 5. 
Table 4. Frequency of the clinical signs detected in PDSA sows

\begin{tabular}{cccccccc}
\hline Clinical signs & $\begin{array}{c}\text { Altered piglet's } \\
\text { behavior }\end{array}$ & Hypogalactia & Endometritis & $\begin{array}{c}\text { Depression } \\
\text { in sows }\end{array}$ & Mastitis & Fever & Anorexia \\
\hline $\begin{array}{c}\text { PDSA sows \% } \\
(\mathbf{n}=\mathbf{4 7})\end{array}$ & 68.1 & 63.8 & 63.8 & 59.6 & 42.6 & 36.2 & 34.0 \\
\hline
\end{tabular}

Table 5. Frequency of the clinical signs detected in PDSA sows from different farms

\begin{tabular}{llllll}
\hline Clinical sings & $\begin{array}{l}\text { Farm A \% } \\
\mathbf{n = 1 6}\end{array}$ & $\begin{array}{l}\text { Farm B \% } \\
\mathbf{n = 8}\end{array}$ & $\begin{array}{l}\text { Farm C \% } \\
\mathbf{n = 4}\end{array}$ & $\begin{array}{l}\text { Farm D \% } \\
\mathbf{n = 1 3}\end{array}$ & $\begin{array}{l}\text { Farm E \% } \\
\mathbf{n = 6}\end{array}$ \\
\hline Fever & $43.8(7 / 16)$ & $12.5(1 / 8)$ & $25.0(1 / 4)$ & $30.8(4 / 13)$ & $66.7(4 / 6)$ \\
Hypogalactia & $62.5^{\mathrm{a}, \mathrm{b}}(10 / 16)$ & $37.5^{\mathrm{b}}(3 / 8)$ & $75.0^{\mathrm{a}, \mathrm{b}}(3 / 4)$ & $92.3^{\mathrm{a}}(12 / 13)$ & $33.3^{\mathrm{b}}(2 / 6)$ \\
Mastitis & $50.0(8 / 8)$ & $25.0(2 / 8)$ & $75.0(3 / 4)$ & $46.2(6 / 13)$ & $16.7(1 / 6)$ \\
Anorexia & $18.8(3 / 16)$ & $12.5(1 / 8)$ & $50.0(2 / 4)$ & $61.5(8 / 13)$ & $33.3(2 / 6)$ \\
Endometritis & $68.8(11 / 16)$ & $75.0(6 / 8)$ & $25.0(1 / 4)$ & $53.9(7 / 13)$ & $83.3(5 / 6)$ \\
Altered piglet's behavior & $75.0^{\mathrm{a}, \mathrm{b}}(12 / 16)$ & $100.0^{\mathrm{a}}(8 / 8)$ & $100.0^{\mathrm{a}, \mathrm{c}}(4 / 4)$ & $46.2^{\mathrm{b}, \mathrm{c}}(6 / 13)$ & $33.3^{\mathrm{b}}(2 / 6)$ \\
Depression in sow & $50.0(8 / 16)$ & $75.0(6 / 8)$ & $75.0(3 / 4)$ & $76.9(10 / 13)$ & $16.7(1 / 6)$ \\
\hline
\end{tabular}

Values in a row marked with different small letters are significantlly different $(\mathrm{a}, \mathrm{b}, \mathrm{c}, \mathrm{p}<0.05)$ from each other

Table 6. Frequency of the clinical signs found in PDSA sows considering the number of parity

\begin{tabular}{cccccccc}
\hline \multirow{2}{*}{ Parity } & \multicolumn{7}{c}{ Clinical signs } \\
\cline { 2 - 8 } & $\begin{array}{c}\text { Altered piglet's } \\
\text { behavior }\end{array}$ & Hypogalactia & Endometritis & $\begin{array}{c}\text { Depression } \\
\text { in sows }\end{array}$ & Mastitis & Fever & Anorexia \\
\hline \multirow{2}{*}{$\mathbf{1 - 2}(\mathbf{n}=\mathbf{2 7}) \%$} & 74.1 & 74.1 & $44.4^{\mathrm{y}}$ & 63.0 & 33.3 & $22.2^{\mathrm{b}}$ & 44.4 \\
& $(20 / 27)$ & $(20 / 27)$ & $(12 / 27)$ & $(17 / 27)$ & $(9 / 27)$ & $(6 / 27)$ & $(12 / 27)$ \\
\hline \multirow{2}{*}{$\mathbf{3}(\mathbf{n}=\mathbf{2 0}) \%$} & 60.0 & 50.0 & $90.0^{\mathrm{x}}$ & 55.0 & 55.0 & $55.0^{\mathrm{a}}$ & 20.0 \\
& $(12 / 20)$ & $(10 / 20)$ & $(18 / 20)$ & $(11 / 20)$ & $(11 / 20)$ & $(11 / 20)$ & $(4 / 20)$ \\
\hline
\end{tabular}

Values in a column marked with different small letters are significantlly different $\left({ }^{a, b} \mathrm{p}<0.05 ;{ }^{x, y} \mathrm{p}<0.01\right)$

Concerning the clinical signs between PDSA sows of different parity, significant differences were found in the frequency of endometritis $(\mathrm{p}<0.01)$ and fever $(p<0.05)$. Thus, endometritis was more often detected in older sows $[90 \%(18 / 20)]$ in comparison to younger sows $[44.4 \%(12 / 27)]$. Furthermore, fever was more observed also in higher parity $[55 \%$ $(11 / 20)]$ in contrast to lower parity sows $[22.2 \%$ $(6 / 27)]$. The frequency of the clinical signs related with PDSA sows of different parity is demonstrated in Table 6.

\section{DISCUSSION}

This study confirmed the presence of PDS in farmed sows in the RM. The prevalence was determined at sow and farm level, whereas sows were classified as PDS-affected if at least two clinical signs were found 12 to 24 hours postpartum. There are big differences in the literature data regarding criteria used to define the severity and occurrence of PDS, either at animal (2, 11, 14, $22,23,24)$ or herd level (6). Thus, the prevalence data for PDS between different studies are quite difficult to compare. This research showed a higher PDS prevalence (23.3\%) compared to the prevalence obtained in the studies of Backstrome et al. $(19 ; 6.9 \%)$ and Threlfall and Martin $(22 ; 13 \%)$, but lower than the study conducted by Larsen and Thorup (23; 32.5\%). However, the huge differences found in the prevalence between the farms in RM $(14.8-38.1 \%)$ is in agreement with the study of Backstrome et al. (19; 1.1\%-37.2\%). In our study, the higher prevalence of PDS in youger sows (13.4\%) in contrast to the older sows $(9.9 \%)$ is in accordance with the findings of Bostedt et al. (25) and Hoy et al. (26), but disagrees with the results reported by 
Backstrome et al. (19). The last one, found less prevalence in primiparous sows $(4.2 \%)$ unlike in multiparous sows where the PDS prevalence was $13 \%$. Variability in the prevalence between the studies is most likely due to the influence of certain risk factors responsible for the clinical manifestation of PDS such as feeding (27), housing (19), microclimate conditions (28), management (6) and hygiene practices implemented in the farms (29).

Measuring of the rectal temperature in sows after farrowing is the most frequent clinical parameter used for PDS diagnosis in sows $(1,30)$. Thus, increased rectal temperature above a certain threshold is used to categorize postparturient sows as being affected by PDS (18). Since physiological hyperthermia in sows is often seen and could reach up to $40.5^{\circ} \mathrm{C}$ (31), the recommended threshold for rectal temperature in sows should be $39.5^{\circ} \mathrm{C}$, when measured 12 to 24 hours after completion of the farrowing (10). In this context, increased rectal temperature should not be the only criterion used for PDS diagnosis in sows, but other clinical parameters such as reduced appetite, endometritis, hypogalactia and mastitis, sow demeanor and altered piglet's behavior should be also included $(2,6,11,32,33)$. In our research, PDS in sows was defined 12 to 24 hours after farrowing and besides increased rectal temperature $\left(\geq 39.5^{\circ} \mathrm{C}\right)$, other previously described clinical criteria were also used. The low percentage of PDSA sows with increased rectal temperature $(36.2 \%)$ is in line with the data demonstrated in recent literature (14), where most of the PDSaffected sows with reduced milk production in early postpartum period had normal rectal temperatures. Additionally, the significantly higher frequency of increased rectal temperature in older sows $(55 \%, 12 / 20)$ is in accordance with the findings of Tummaruk and Sang-Gassanee (17), who reported fever in $52.6 \%$ and $47.6 \%$ of sows parity $2-4$ and 5-7 respectively. The low percentage of increased rectal temperature in younger PDSA sows $(22.2 \%)$ in our study compared to $93.7 \%$ of primiparous sows with fever detected by Tummaruk and Sang-Gassanee (17) is most probably due to the higher threshold of increased rectal temperature $\left(\geq 39.5^{\circ} \mathrm{C}\right.$ vs. $\left.\geq 39.0^{\circ} \mathrm{C}\right)$ used to define fever in PDS affected sows.

There are many clinical studies which have investigated the periparturient health status in sows $(8,18,19,20,22,24,30,34)$. In most of these studies, assessment of the piglet's behavior as one of the most important diagnostic criterion associated with PDS (14) was missing. Early detection of these litters is essential especially in the first days after farrowing, since it is a very sensitive period in pig production (14). Decreased piglet's growth in affected litters can be detected, if there is increased heterogeneity between the piglets at the first week of age and at weaning age, as well as if the weaning weight is low (35). In our study the altered piglet's behavior expressed as a lethargy and decreased nursing frequency was the most frequent clinical parameter (68.1\%) found among the litters. This result confirmed the clinical importance of assessing the piglet's behaviour in order to detect lactation problems in sows during early postpartum period.

The prevalence of anorexia, fever and endometritis in PDSA sows conforms with the findings of Miquet et al. (36) and Madec and Leon (18). Furthermore, clinical mastitis was more prevalent $(42.6 \%)$ in our research compared to the results reported by Hirsch et al. (11; 3\%), Miquet et al. $(36 ; 2 \%)$ and Madec and Leon (18; 3.3\%).. On the other hand, prevalence of the clinical changes of mammary glands in PDSA sows is similar to the data obtained by other authors $(8,15,19$, 37). In addition, the type of the clinical changes in mammary glands may serve as indicators for estimation of the post-partum health status in sows (38). Despite the precence of mastitis, milk flow rate is very important clinical parameter for assessment of the function of mammary glands $(2,11)$. This diagnostic criterion for defining PDS in sows is explained in more details by Hirsch et al. (11) and Van Gelder and Bilkei (2). Nowadays, improvements in intensive pig farms regarding management and health measures substantially decreased the number of clinical mastitis cases in sows after farrowing. This was confirmed in our study where hypogalactia without mastitis was more present in PDSA sows compared to PDSA sows with clinical mastitis followed by hypogalactia or agalactia. Similar findings were revealed by Olson and Bilkei (39), who reported a higher percentage of diseased sows with agalactia and without mastitis $(28.9 \%)$ in contrast to PDSA sows that displayed mastitis and agalactia (24.4\%).

The high percentage of purulent vaginal discharges in PDSA sows (63.8\%) in this research was similar to the percentage of purulent vaginal discharges in MMA sows (58\%) found by Hirsch et al. (11). Higher frequency of endometritis in higher parity sows (90\%) versus lower parity sows (44.4\%) is in agreement with the data of Tummaruk and Sang-Gassanee (17), who found higher incidence of vaginal discharge at the first day postpartum in sows of higher parity 5-7 than sows of parity $2-4(85.7 \%$ 
vs. 52.6\%). In the recent studies by Peltoniemi et al. (16) and Tummaruk and Sang-Gassanee (17), it was demonstrated that farrowing duration and occurrence of endometritis had great influence in the development of PDS in sows first three days post-partum. These two studies have proven the negative impact of prolonged farrowing on the health status of sows. According to Peltoniemi et al. (16), sows with an enlarged uterus had a longer and more difficult parturition than other sows. Sows with enlarged uterus and prolonged farrowing duration in the early post-partum period exhibited clinical endometritis, which is considered as one of the most important risk factors that affects PDS manifestation. The high percentage of PDSA sows with endometritis in our study especially in older sows $(90 \%)$ confirmed the conclusion of Peltoniemi et al. (16) that clinical endometritis is strongly associated with the health status of the sows in postpartum period.

\section{CONCLUSION}

Our results indicate that clinical examination 12-24 hours after farrowing confirms the presence of PDS in farmed sows in RM. The high frequency of altered piglet's behavior found in this study could be used as a strong indicator for an early detection of lactation problems in sows. Frequent pathological vaginal discharge in higher parity sows indicates that endometritis plays an essential role in the clinical occurrence of PDS. However, additional research is needed to identify the relation between certain risk factors and clinical appearance of PDS at the commercial pig farms in RM.

\section{CONFLICT OF INTEREST}

The authors declared that they have no potential conflict of interest with respect to the authorship and/or publication of this article.

\section{ACKNOWLEDGEMENTS}

The authors would like to thank the colleagues from pig farms for their contribution to this study. The five pig producers are acknowledged for their willingness to participate in this study.

\section{REFERENCES}

1. Gerjets, I., Kemper, N. (2009). Coliform mastitis in sows: a review. J Swine Health Prod. 17, 97-105.

2. Van Gelder, K.N., Bilkei, G. (2005). The course of acute-phase proteins and serum cortisol in mastitis metritis agalactia (MMA) of the sow and sow performance. Tijdschr Diergeneesk. 130, 38-41. PMid:15709617

3. Maes, D., Papadopoulos, G., Cools, A., Janssens, G.P.J. (2010). Postpartum dysgalactia in sows: pathophysiology and risk factors. Tierarztl Prax. 38, 15-20.

4. Klopfenstein, C., Farmer, C., Martineau, G.P. (1999). Diseases of the mammary glands and lactation problems. In: B.E. Straw, W.L. Mengeling, S. D'Allaire, D.J. Taylor, (Eds.), Diseases of Swine 8th ed. (pp.833-860). Ames, IA, USA: Iowa University Press.

5. Kemper, N., Bardehle, D., Lehmann, J., Gerjets, I., Looft, H., Preißler, R. (2013). The role of bacterial pathogens in coliform mastitis in sows. Berl Munch Tierarztl. 126, 130-136.

6. Papadopoulus, G., Vanderhaeghe, C., Janssens, G.P.J., Dewulf, J., Maes, D. (2009). Risk factors associated with postpartum dysgalactia syndrome. Vet J. 187, 167-171.

7. Angjelovski, B., Cvetkovikj, A., Mrenoshki, S., Radeski, M., Cvetkovikj, I., Ratkova, M., Dovenski, T. (2016). Bacteria associated with clinical postpartum dysgalactia syndrome in farmed sows in the Republic of Macedonia. Turk J Vet Anim Sci. 40, 776-781.

https://doi.org/10.3906/vet-1602-102

8. Wegman, P., Bertschinger, H.U., Jecklin, H. (1986). A field study on the prevalence of coliform mastitis (MMA syndrome) in Switzerland and the antimicrobial susceptibility of the coliform bacteria from the milk. Proceedings of the $9^{\text {th }}$ Int. Vet. Pig. Soc. Congr. July, 15-18, (pp. 92-92), Barcelona, Spain.

9. Awad Masalmeh, M., Baumgartner, W., Passernig, A., Silber, R., Hinterdorfer, F. (1990). Bacteriological studies of the mastitis- metritisagalactiasyndrome in Austrian pig farms. Tierärztl Umsch. 45, 526-535.

10. Kemper, N., Gerjets, I. (2009). Bacteria in milk from anterior and posterior mammary glands in sows affected and unaffected by postpartum dysgalactia syndrome (PPDS). Acta Vet Scand. 51, 26-32.

https://doi.org/10.1186/1751-0147-51-26

PMid:19545415 PMCid:PMC2704218 
11. Hirsch, A.C., Philipp, H., Kleemann, R. (2003). Investigation on the efficacy of meloxicam in sows with mastitis-metritis-agalactia syndrome. $\mathrm{J}$ Vet Pharmacol Ther. 26, 355-360.

https://doi.org/10.1046/j.1365-2885.2003.00524.x PMid:14633188

12. Bertschinger, H.U., Bürgi, E., Eng, V., Wegmann, P. (1990). Lowering of the incidence of puerperal mastitis in the sow by protection of the mammae from contamination. Schweiz Arch Tierh. 132, 557-566. PMid:2270453

13. Martineau, G.P. (2005). Postpartum dysgalactia syndrome and mastitis in sows. In: C.M. Kahn (Ed.), The Merck Veterinary Manual. $9^{\text {th }}$ ed. (pp. 1134-1137). New York, USA: Merck.

14. Martineau, G.P., Farmer, C., Peltoniemi, O. (2012). Mammary system. In: J.J. Zimmerman, A.L. Karriker, A. Ramirez, J.K. Schwartz, W.G. Stevenson, (Eds.), Diseases of Swine $10^{\text {th }}$ ed. (pp. 273-293). Oxford, UK: Wiley-Blackwell.

15. Ross, R.F., Orning, A.P., Woods, R.D., Zimmermann, B.J., Cox, D.F., Harris, D.L. (1981). Bacteriologic study of sow agalactia. Am J Vet Res. 42, 949-955. PMid:7025714

16. Peltoniemi, O.A.T., Björkman, S., Oliviero, C. (2016). Parturition effects on reproductive health in the gilt and sow. Reprod Domest Anim. Suppl. 51, 36-47.

https://doi.org/10.1111/rda.12798

PMid:27762056

17. Tummaruk, P., Sang-Gassanee, K. (2013). Effect of farrowing duration, parity number and the type of anti-inflammatory drug on postparturient disorders in sows: a clinical study. Trop Anim Health Pro. 45, 1071-1077.

https://doi.org/10.1007/s11250-012-0315-X

PMid:23143739

18. Madec, F., Leon, E. (1992). Farrowing disorders in the sow - a field-study. J Vet Med A. 39, 433-444. https://doi.org/10.1111/j.1439-0442.1992.tb00202.x

19. Bäckström, L., Morkoc, A.C., Connor, J., Larson, R., Price, W. (1984). Clinical study of mastitis-metritisagalactia in sows in Illinois. J Am Vet Med Assoc. 185, 70-73.

PMid:6746376

20. Thorup, F. (2000). Effect of treatment for MMAretrospective observations. Proceeding of the 16th Int. Vet. Pig. Soc. Congr. June, 17-21, (pp 97-97), Melbourne, Australia.

21. Bäckström, L. (1973). Environment and animal health in piglet production. Acta Vet Scand. Suppl. 41, 1-240.
22. Threlfall, W.R., Martin, C.E. (1973). Swine agalactia in Missouri. Vet Med Small Anim Clin. 68, 423-426. PMid:4487944

23. Larsen, I., Thorup, F., (2006). The diagnosis of MMA. Proceeding of the 19th Int. Vet. Pig. Soc. Congr. July, 16-19, (pp. 256.), Copenhagen, Denmark. PMid:16526496

24. Jorsal, S.E. (1986). Epidemiology of the MMA syndrome. A field survey in Danish sow herds. Proceedings of the $9^{\text {th }}$ Int. Vet. Pig. Soc. Congr. July, 15-18, (pp. 93.), Barcelona, Spain.

25. Bostedt, H., Maier, G., Herfen, K., Hospen, R. (1998). Clinical examinations on gilts with pueperal septicaemia and toxaemia. Tierarztl Prax. 26, 332-338.

26. Hoy, S (2002). Investigations on influence of different housing factors on frequency of puerperal diseases in sows. Praktischer Tierarzt. 83, 990-996.

27. Oliviero, C., Kokkonen, T., Heinonen, M., Sankari, S., Peltoniemi, O. (2009). Feeding sows with different amount of fibre during late pregnancy, farrowing and early lactation: Impact on the intestinal function, the energy balance and the litter. Res Vet Sci. 86, 314-319. https://doi.org/10.1016/j.rvsc.2008.07.007 PMid:18725160

28. Klopfentein, C., D'Allaire, S., Martineau, G.P. (1995). Effect of adaptation to the farrowing crate on water intake of sows. Livest Prod Sci. 43, 243-252. https://doi.org/10.1016/0301-6226(95)00047-O

29. Hultén, F., Persson, A., Eliasson-Selling, L., Heldmer, E., Lindberg, M., Sjögren, U., Kugelberg, C., Ehlorsson, C.J. (2004). Evaluation of environmental and management-related risk factors associated with chronic mastitis in sows. Am J Vet Res. 65, 1398-1403. https://doi.org/10.2460/ajvr.2004.65.1398 PMid:15524327

30. Furniss, S.J. (1987). Measurement of rectal temperature to predict mastitis, metritis and agalactia (MMA) in sows after farrowing. Prev Vet Med. 5, 133-139. https://doi.org/10.1016/0167-5877(87)90018-3

31. Messias de Braganca, M., Mounier, A.M., Hulin, J.C., Prunier, A. (1997). La sous-nutrition explique-t-elle les effets d'une température ambiante élevée sur les performances des truies? Journ Rech Porcine France. 29, 81-88.

32. Alexopoulos, C., Georgoulakis, I.E., Tzivara, A., Kritas, S.K., Siochu, A., Kyriakis, S.C. (2004). Field evaluation of the efficacy of a probiotic containing Bacillus licheniformis and Bacillus subtilis spores, on the health status and performance of sows and their litters. J Anim Physiol a Anim Nutr. 88, 381-392. https://doi.org/10.1111/j.1439-0396.2004.00492.x PMid:15584947 
33. Radostits, O.M. (2005). Mastitis-Metritis-Agalactia syndrome in sows. In: O.M. Radostits, C.C. Gay, D.C. Blood, K.W. Hinchclif, (Eds.), Mastitis. Veterinary Medicine: A Textbook of the diseases of cattle, sheep, pigs, goats and horses (pp.692-697). WB Saunders.

34. Ringarp, N. (1960). Clinical and experimental investigations into a post- parturient syndrome with agalactia in sows. Acta Agric Scand. Suppl. 7, 166-166.

35. Martineau, G.P., Smith, B.B., Doize, B. (1992). Pathogenesis, prevention and treatment of lactational insufficiency in sows. Vet Clin North Am Food Anim Pract. 8, 661-683. https://doi.org/10.1016/S0749-0720(15)30710-6

36. Miquet, J.M., Madec, F., Paboeuf, F. (1990). Epidemiologie des troubles de la mise bas chez latruie: Premiers resultats d'une etude realisee dans deuxélevages. J Rech Porcine en France. 22, 325-332.
37. Heinritzi, K., Hagn, J. (1999). Comparison of therapeutic performance of the new Cephalosporin Cefquinome with other treatment regimes in gilts with puerperal septicaemia and toxaemia syndrome. Tierärztl Prax. 27, 114-121. [in German]

38. Kopinski, J.S., Blaney, B.J., Downing, J.A., McVeigh, J.F., Murray, S.A. (2007). Feeding sorghum ergot (Claviceps africana) to sows before farrowing inhibits milk production. Aust Vet J. 85, 169-176.

https://doi.org/10.1111/j.1751-0813.2007.00139.x PMid:17470063

39. Olson, P.M., Bilkei, G. (2004). Bacterial flora of vulval discharges and mammary secretions in sows suffering peri-parturient diseases in a large indoor breeding unit. Pig Journal 54, 45-54. 